\title{
A Review on the Use and Perceived Effects of Mobile Blogs on Learning in Higher Educational Settings
}

\author{
Helmi Norman ${ }^{1}$, Rosseni Din $^{1}$, Norazah Nordin ${ }^{2} \&$ Thomas Ryberg ${ }^{3}$ \\ ${ }^{1}$ Personalized Education Research Group, Faculty of Education, National University of Malaysia, Bangi, \\ Malaysia \\ ${ }^{2}$ Faculty of Education, National University of Malaysia, Bangi, Malaysia \\ ${ }^{3}$ e-Learning Lab, Department of Communication and Psychology, Aalborg University, Aalborg, Denmark \\ Correspondence: Rosseni Din, Department of Education and Community Wellness, National University of \\ Malaysia, 43600, Bangi, Malaysia. Tel: 60-3-8921-6281.E-mail: rosseni@ukm.my; rosseni@yahoo.com
}

Received: September 24, 2013 Accepted: October 25, 2013 Online Published: December 31, 2013

doi:10.5539/ass.v10n1p209

URL: http://dx.doi.org/10.5539/ass.v10n1p209

\begin{abstract}
Mobile technology is affecting the way we learn and teach in higher education. An interesting mobile tool for supporting learning and instruction is by using mobile blogs or "moblogs". This review focuses on existing studies implementing moblogs for learning purposes in higher educational settings. A total of 16 studies were selected for the review. The constant-comparative method was used to analyze the studies. Results from the data analysis indicate that the findings fall into two overarching groups, which are: (i) usage of moblogs; and (ii) perceived effects of moblogs. Seven categories for moblog usage were identified, namely: (i) moblogs were used for context-sensitive learning; (ii) for collaboration in groups; (iii) as a tool for interaction and communication for learning; (iv) as personal learning diaries; (v) to facilitate learning at students' own time and pace; (vi) as a tool for feedback on instruction; and (vii) for reflections in learning. Meanwhile, three categories were discovered for perceived effects of moblogs, which are: (i) perceived affective effects in terms of satisfaction and attitude; (ii) perceived social effects on students; and (iii) negative perception of moblog in terms of personal and technical factors. These categories are discussed as factors that could promote the use of moblogs for learning in higher education. Directions for future research are also discussed according to these categories as a basis for future work on moblogs for learning.
\end{abstract}

Keywords: moblogs, mobile blogs, usage of mobile blogs, perceived effects of mobile blogs, higher education

\section{Introduction}

Mobile learning or "m-learning" has seen rapid development in recent years and is currently changing teaching and learning in higher educational institutions leading to new pedagogical approaches (Sharples et al., 2009). This growth has been aided by advancements in mobile technology such as the introduction of 3G or third generation wireless system (Ekström et al., 2007) allowing high-speed web service over the Internet, as well as production of mobile devices that includes tablet PCs (e.g. Apple iPad, Samsung Galaxy Tab) and multimedia-enabled smartphones. As mobile technology's nature is wireless, it allows users of m-learning to study just about anything, anywhere and at anytime (Ally, 2009; Sharples et al., 2009; Traxler, 2009; Siraj \& Norman, 2011). One of the mobile web 2.0 technologies that show promise in facilitating teaching and learning is mobile blogs or "moblogs". Yet, the implementation of moblog technology in higher educational institutions is relatively new (Hwang et al., 2008; Huang et al., 2009; Traxler, 2009), thus calling for a need for further investigation of their role in learning and instruction (Ryberg \& Christiansen, 2008; Nordin et al., 2010; Din et al., 2011; Wong \& Lui, 2011; Hussin et al., 2012). Thus, in an attempt to understand moblogs' role in learning and instruction, this paper reviews the previous and current empirical research on moblogs in higher educational settings. The paper starts with a brief description and features of moblogs, which is then continued by a discussion of the sources and method used in gathering the data. This is then followed by an explanation of our findings and discussion related to the findings. In the discussion and conclusion sections, future directions are suggested for the use of moblogs in higher education. 


\section{Background}

TNS, the world's largest custom research company, reported that from 34,000 respondents surveyed in 43 countries, the number of web users visiting social networking sites (supported by web 2.0 technologies) on mobile platforms has increased from $30 \%$ to $46 \%$ in 2011 . The ownership of tablet computers has also grown; with intended rates of $31 \%$ in Asia and 28\% in Europe (TNS, 2011). This shows a huge potential in integrating web 2.0 in mobile and wireless technologies in the current global and local educational sectors.

The term "moblog" is a combination of two terms, mobile and weblogs. It was coined by Adam Greenfield in 2002 (Ito, 2002) who later in 2003 organized the first International Moblogging Conference "1IMC" in Tokyo (Doring \& Gundolf, 2006). Moblogs serve as a platform to allow users to send, edit and publish their postings via logging into the moblog platform or via mobile messaging (SMS or MMS). In addition, the platform also enables users to send and receive messages between other mobile bloggers, make personal profiles and produce topical mobile circles (Doring \& Gundolf, 2006).

Research suggests that moblogs consist of the following features:

1) Chronological order postings. Similar to blogs Moblogs consist of a series of chronologically ordered web publications that are usually in reverse chronological order (Herring et al., 2004; Doring \& Gundolf, 2006).

2) Personal publishing. Moblogs allow mobloggers to create their own personalized content to be shared with their peers or the public. In some moblogs, contributions are produced directly and indirectly from public readers and links with external blogs and websites (Doring \& Gundolf, 2006).

3) Instant sharing of postings. In contrast to weblogs, moblogs allow for spontaneous share of moblog postings based on the location and position of the moblogger as well as the surrounding environment (Richardson et al., 2007).

4) Photography/videography support. Another feature that distinguishes moblogs from weblogs is the photography/videography support facilitated by mobile devices used. Doring \& Gundolf (2006) reported that this feature promotes photographic experimentation, expression of thoughts via pictures, as well as a community that is more visually competent.

\section{Data Collection and Analysis}

The search for articles was performed in two phases. The first phase was conducted using online databases such as Web of Science, ERIC, Scopus Sciverse and Google Scholar. In the second phase, an advanced search was conducted. Only research on studies that was conducted with higher education students was considered. The main criteria used for selection of articles were articles that contained the following descriptors: (i) mobile blogs or moblogs; (ii) mobile blogging or moblogging; and (iii) higher education. Articles that were targeted were related to students using moblog technology in higher educational institutions. As a result, 16 studies were identified for review (summarized in Table 1). Articles that were not related to moblogs for instruction and learning in higher education context (e.g. the use of moblogs in traveling) were not included in the review, but were used as reference where suitable. All the studies performed data collection via surveys, interviews or analysis of moblog content. Survey was the most frequent data collection tool used.

This review adapts the method of data analysis used in Sim \& Hew's (2010) study. In the method, the constant-comparative approach is utilized to cluster relating themes in the reviewed articles. These themes (referred to as categories) are identified on an inductive basis based on the data instead of predetermined by prior analysis. Explicitly, this method involved the following procedures: (i) analysis of individual articles; (ii) category formation; (iii) category comparison; and (iv) category saturation. Through these steps, the articles are analyzed individually and categories are formed based on the themes identified. Upon identification of new emerging themes, the themes were checked and categorized according to their relevant categories (category saturation) to avoid redundancy. It is worth noting that a single article can result in two or more categories. 
Table 1. Summary of reviewed studies

\begin{tabular}{|c|c|c|c|c|c|}
\hline Studies & Participants & $\begin{array}{l}\text { Context of } \\
\text { moblog }\end{array}$ & $\begin{array}{l}\text { Research/evaluation } \\
\text { methodology }\end{array}$ & $\begin{array}{l}\text { Evaluation } \\
\text { type }\end{array}$ & Findings \\
\hline Beale (2006) & $\begin{array}{l}6 \text { users from } \\
\text { University of } \\
\text { Birmingham, in } \\
\text { United Kingdom. }\end{array}$ & $\begin{array}{lr}\text { A moblog } & \text { was } \\
\text { created } & \text { to } \\
\text { interaction } & \\
\text { between } & \\
\text { students } & \text { and } \\
\text { staff. } & \end{array}$ & 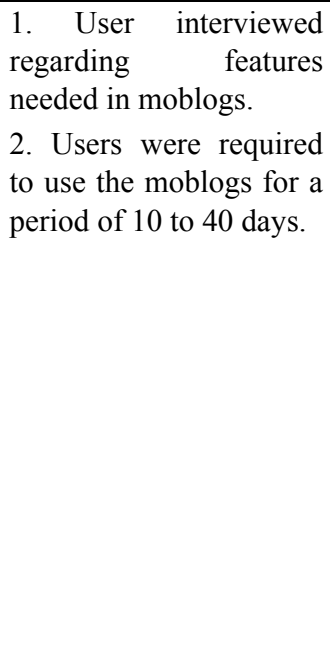 & Interview & $\begin{array}{lr}\text { Users } & \text { were } \\
\text { interested } & \text { in } \\
\text { producing } & \\
\text { multimedia } & \text { on } \\
\text { their mobile } \\
\text { phones and } \\
\text { uploading it to } \\
\text { their moblogs. } \\
\text { They also found } \\
\text { out that moblogs } \\
\text { allowed instant } \\
\text { sharing of photos } \\
\text { with peers. In } \\
\text { addition, they } \\
\text { stated that the } \\
\text { moblogs were fun } \\
\text { and easy to use. }\end{array}$ \\
\hline $\begin{array}{l}\text { Cochrane } \\
(2008)\end{array}$ & $\begin{array}{l}8 \text { students of } \\
\text { Diploma } \\
\text { Landscape } \\
\text { Design (in 2007), } \\
8 \text { students from } \\
\text { Bachelor } r \text { of } \\
\text { Product Design } \\
(2008), \quad 11 \\
\text { students from } \\
\text { Diploma of } \\
\text { Contemporary } \\
\text { Music (2008), } \\
\text { and } \\
4 \text { students from } \\
\text { Diploma of } \\
\text { Landscape } \\
\text { Design (2008) of } \\
\text { Unitec in New } \\
\text { Zealand. }\end{array}$ & $\begin{array}{l}\begin{array}{l}\text { Students } \\
\text { assigned } \\
\text { create }\end{array} \text { and } \\
\text { maintain } \\
\text { moblogs } \\
\text { groups. Several } \\
\text { web 2.0 tools } \\
\text { were also used } \\
\text { with } \\
\text { smartphones for } \\
\text { content creation. }\end{array}$ & $\begin{array}{l}\text { 1. Constructivist } \\
\text { learning approach was } \\
\text { used. } \\
\text { 2. The period of study } \\
\text { was one semester. } \\
\text { 3. Students created their } \\
\text { moblogs in groups. } \\
\text { 4. Tutors were required } \\
\text { to give feedback on } \\
\text { moblogs created by } \\
\text { students. }\end{array}$ & $\begin{array}{l}\text { Survey, } \\
\text { interviews and } \\
\text { moblog content } \\
\text { analysis }\end{array}$ & $\begin{array}{l}\text { Findings revealed } \\
\text { that: (i) students } \\
\text { found moblogs to } \\
\text { be convenient, (ii) } \\
\text { several students } \\
\text { moblogs preferred } \\
\text { video compared to } \\
\text { text-based } \\
\text { moblogs, (iii) } \\
\text { student expect } \\
\text { tutors to give } \\
\text { feedback on a } \\
\text { regular basis, (iv) } \\
\text { students stated that } \\
\text { creation and } \\
\text { updating of } \\
\text { moblogs and peer } \\
\text { commenting } \\
\text { require a lot of } \\
\text { time. }\end{array}$ \\
\hline $\begin{array}{l}\text { Comas-Quinn } \\
\text { et al. (2009) }\end{array}$ & $\begin{array}{l}8 \text { students } \\
\text { learning about the } \\
\text { concept of } \\
\text { intercultural } \\
\text { awareness }\end{array}$ & $\begin{array}{l}\text { Students were } \\
\text { assigned to } \\
\text { upload materials } \\
\text { in their blogs as } \\
\text { well as produce } \\
\text { audio recordings }\end{array}$ & $\begin{array}{l}\text { 1. Informal feedback } \\
\text { from students }\end{array}$ & Questionnaire & $\begin{array}{lr}\text { The study found } \\
\text { out that: } \\
\text { students } \\
\text { motivated } \\
\text { interact } \\
\text { moblogs; } \\
\text { students } \\
\text { difficulties } \\
\text { handling mound } \\
\text { technology; (iii) } \\
\text { students were not } \\
\text { accustomed to } \\
\text { "open-nature" of } \\
\text { learning where } \\
\text { they had to set } \\
\text { their own learning } \\
\text { goals. }\end{array}$ \\
\hline
\end{tabular}




$\begin{array}{lllr}\text { Cook et al. } & 22 & \text { students } & \text { Student were } \\ \text { (2011); Smith } & \text { taking Urban } & \text { divided into } \\ \text { et al. (2011) } & \text { Education course } & \text { pairs of three } \\ \text { and were given } & \\ & & \text { mobile phones. } \\ & \text { They were } \\ & \text { assigned to use } \\ & \text { the augmented } \\ & \text { reality and keep } \\ & \text { audio moblogs } \\ & \text { for reflection. }\end{array}$

Davis et al. 40 students from (2005)
Photos taken by

University of students were

California,

United States of

America. automatically

upload to

moblogs and shared photos with peers.

Students were required create entries regarding their daily lives.

\author{
1. Informal \\ interview \\ 2. Questionnaire
}

group interviews

1. Take photos for Survey, interviews and moblog content mobile phone.

analysis

2. Share photos with peers.

3. Duration of study is six weeks.

Haddon and 4 students from a Kim (2007) communication course of Hallym University, Korea.
1. Student were required to fo fill moblogs with text and pictures.

2. Duration of study was one week.
Interviews and moblog content analysis
Results indicated that automatic upload photo feature to moblog increases student's motivation to share photos with peers.

Findings indicated that:

(i) uploading pictures directly from camera phones to moblogs are an important feature to be included in moblogs, (ii) students have a sense of peer pressure to update their moblogs frequently so as to be not left out the community.

Students had a high level of satisfaction in their learning process of creating a video moblog, and upon completion of the product.

\begin{tabular}{|c|c|c|c|c|}
\hline $\begin{array}{l}\text { Herrington } \\
\text { (2009) }\end{array}$ & $\begin{array}{l}14 \text { students } \\
\text { majoring in } \\
\text { Education of } \\
\text { Wollongong } \\
\text { University in } \\
\text { Australia. }\end{array}$ & $\begin{array}{l}\text { Students were } \\
\text { required to } \\
\text { create a } 2 \text { to } 3 \\
\text { minute teacher } \\
\text { episode using a } \\
\text { mobile phone } \\
\text { and upload as } \\
\text { video moblog. }\end{array}$ & 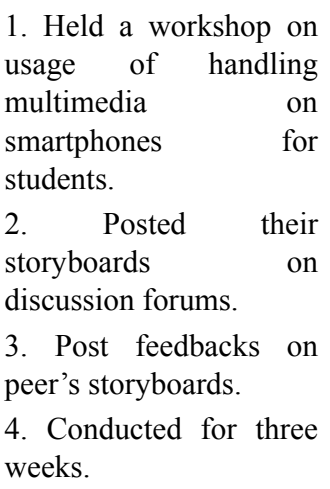 & Interviews \\
\hline $\begin{array}{l}\text { Huang et al. } \\
(2009)\end{array}$ & $\begin{array}{lr}40 & \text { college } \\
\text { students } & \text { who } \\
\text { major } & \text { in } \\
\text { engineering } & \\
\text { science } & \text { of }\end{array}$ & $\begin{array}{l}\text { Students used } \\
\text { moblogs } \\
\text { containing } \\
\text { images, audio } \\
\text { and video for }\end{array}$ & $\begin{array}{l}\text { 1. Divided into groups } \\
\text { and each group given a } \\
\text { discussion topic. } \\
\text { 2. Collaborate via } \\
\text { discussion }\end{array}$ & Survey \\
\hline
\end{tabular}

Findings showed that:

(i) moblogs can be used for collaborative 
National Cheng Kung University in Taiwan.
Killi et al. 8 students taking (2009)
Laine Suhonen (2008) and 9 students taking of a programming project University from Joensuu Finland
Video moblogs were created to learn about $\mathrm{HCI}$ Interaction (HCI) from Satakunta University of Applied Sciences in Finland. collaborative learning. answering questions in moblog.

3. Produce a report containing learning material, lecture notes and discussion. learning as well as motivate them to collaborate with each other, (ii) students consider moblogs to allow them in obtaining authentic context learning examples and share them with their colleagues, (iii) students can interact with moblogs in the same way as they interact in blogs, but moblogs provides an advantage in terms of mobility.

1. Students were Interviews,

Video moblogging required to listen to a survey and one-hour lecture. moblog content 2. Student were tested analysis two times, pre-test and post-test.

3. Students made their video moblogs individually during a period of three weeks.

Students were Students created entries Survey required to in moblogs for a period create postings of three weeks. in moblogs on the subject of programming.
Morken and 30 students Divitini (2005) taking Practical Pedagogical Education course at Norwegian
Students teachers cooperate among another and

Students were provided with moblogs that supported uploading of pictures and sending SMS (short message as identified as an

effective learning approach for most of the students.

They stated that preparation and making video blog posts was challenging. They also face difficulties during capturing videos due to lack of conceptual understanding of a particular subject.

1. Moblogs are observed to be an effective reporting tool.

2. It is recommended that moblogs be used for reflection for amateur users and be used for collaboration as students get use to moblog's

functionalities.

$\begin{array}{lr}\text { Shared } & \text { ambient } \\ \text { displays } & \text { were } \\ \text { preferred } & \text { as } \\ \text { compared } & \text { to } \\ \text { moblogs as } & \text { these }\end{array}$ 


$\begin{array}{lrlrl}\text { University } & \text { of } & \text { moblogs. } & \text { service) messages via } \\ \text { Science } & \text { and } & \text { Moblogs were their mobile phones. } \\ \text { Technology } & \text { in } & \text { also used as a } & \text { This allowed for } \\ \text { Norway. } & & \text { platform to students to gather pieces } \\ & \text { allow students to of information. } \\ & \text { publish and } \\ & \text { share their } \\ & \text { experience with } \\ & \text { other students } \\ & \text { for reflection. }\end{array}$

Oliver and 290 engineering Goerke (2007) students at Curtin University of Technology in Australia.

33 students in French class from Caen University France and two other students (one from Norway and the other from France).

Petersen (2007)
Moblogs were provided students studying purposes.
Students were accessed on their usage of moblogs in the mobile learning project which they participated in.

\section{to}

for

(1)
Survey

Community moblogs were developed to create community between students learning language and create a sense of belonging to the community.

\section{Evaluated for 11 Survey,} weeks.

2. Two students were semi-structured diaries two times a week for a 4 week period.

3. The two student were required to contribute regularly to encourage other student to contribute as well. asked to submit interviews and moblog content analysis
16
Chinese overseas students in University of Nottingham in the United Kingdom (UK).

Group moblogs were used to share news in students' new learning environment, difficulties in learning and their viewpoints on adapted to new culture and lifestyle.
1. Moblogs were tested Survey, in a period of three weeks.

2. Moblogs created was in the form of text and images.

3. Moblogs were accessible to public but only permitted them to read, registered bloggers were allowed to author and change content of the moblogs. type of displays allow better system visibility. This was due to lack of features supported preventing the user full access to the system provided causing them to fail in noticing new information that has been added.

Only a few students were recorded as frequent users of moblogs, and one fifth of the students used moblogs occasionally for the purpose of studying.

It was reported that there was a low level of contribution from students in the moblogs. This was due to: (i) students not knowing each other, (ii) some cases of failure in instantaneous visibility of moblog updates, and (iii) non-technical users face difficulties in using the moblog.

Findings indicate that group blogs promote collaboration and social communication among users. In moblogs, there is demand in capturing recent events and instantaneously sharing them with other bloggers. 


\begin{tabular}{|c|c|c|c|c|}
\hline Trafford (2005) & $\begin{array}{l}\text { A group of } \\
\text { undergraduates in } \\
\text { Year } 1 \text { Chemistry } \\
\text { course of Oxford } \\
\text { in the UK. }\end{array}$ & $\begin{array}{l}\text { Students use } \\
\text { moblogs to offer } \\
\text { feedback on } \\
\text { lecture courses, } \\
\text { tutorials and } \\
\text { practicals as } \\
\text { well as learning } \\
\text { processes, } \\
\text { teaching style, } \\
\text { academic } \\
\text { provision, } \\
\text { timetabling. } \\
\text { Teachers and } \\
\text { tutors can use } \\
\text { the feedback to } \\
\text { improve their } \\
\text { teaching. }\end{array}$ & $\begin{array}{l}\text { 1. Moblogs were made } \\
\text { in range of one month } \\
\text { per blog. } \\
\text { 2. Entries were } \\
\text { submitted per week. } \\
\text { 3. Moblogs maintained } \\
\text { in a period of } 6 \text { months. }\end{array}$ & Survey \\
\hline Wishart (2009) & $\begin{array}{l}6 \text { teacher trainees } \\
\text { on Postgraduate } \\
\text { Certificate of } \\
\text { Education } \\
\text { (PGCE) course } \\
\text { from the } \\
\text { University of } \\
\text { Bristol in the UK. }\end{array}$ & $\begin{array}{l}\text { Trainee teachers } \\
\text { were required to } \\
\text { create reflective } \\
\text { moblogs to } \\
\text { record lesson } \\
\text { assessments and } \\
\text { teaching } \\
\text { reflections. }\end{array}$ & $\begin{array}{l}\text { 1. Provided with } \\
\text { handheld computers in a } \\
\text { one-year period. } \\
\text { 2. Create moblogs for } \\
\text { teaching refelctions and } \\
\text { be used later for } \\
\text { assignments. } \\
\text { 3. University tutors } \\
\text { check blogs to view } \\
\text { trainee teachers' } \\
\text { teaching progress. }\end{array}$ & urvey \\
\hline
\end{tabular}
Feedback from
students indicated
that moblogs can
be used to express
their views on
pace of teaching
and learning, their
interest on lectures
and their progress
of their work.
Usage of moblogs
is convenient but
tend to promote
short attention
spans among
students.

\section{The Usage and Perceived Effects of Moblogs in Learning}

All the studies reviewed focused mostly on investigation of moblogs for learning. There was no specific discipline that the studies focused on, and studies were conducted in the disciplines of: (i) educational technology (12.5\%); (ii) computer science (12.5\%); (iii) engineering (12.5\%); (iv) intercultural awareness; and (v) the remaining $50 \%$ in landscape, urban education, communication, and language learning.

The data analysis results in the coding of several categories. The categories found seem to gather into two overarching groups, which are "moblog usage in learning" as well as "perceived effects of moblogs for learning". This review identified seven major uses of moblogs in learning. However, it is worth noting that the list of moblog usage in learning does not represent the whole population of moblog usage in learning, but does cover the samples presented in this paper.

\subsection{Moblogs Usage in Learning}

1) Moblogs were used to facilitate context-sensitive learning (Davis et al., 2005; Beale, 2006; Shao et al., 2007; Cochrane, 2008; Laine \& Suhonen, 2008; Huang et al., 2009; Cook et al., 2011; Smith et al., 2011). Huang et al. (2009) reported that students used moblogs to learn about basic concepts in data structure. In the learning activities assigned, students were required to use their surrounding environment to explain data structure concepts. For example, one student took photos (using a mobile device) of people queuing up to describe the concept of queues in data structure. It was concluded that use of the surrounding environment in learning (context sensitive learning) assisted students in visualizing abstract concepts in data structure. Similarly, in Cochrane's (2008) research, moblogs were utilized for a subject on landscape. Students uploaded pictures and videos taken from their smartphones to moblogs as resources and documentation for their course projects. One student stated that moblogs can be used when "spotting something inspirational, documenting an idea, when a PC is not around". It was also reported that moblog usage provided the opportunity for students to apply the theories learnt in classrooms in practice. In relation to this, Smith et al. (2011) combined moblogs with mobile augmented reality. They discovered that this mode of learning helped students in making learning more 
memorable and authentic. This is due to the fact that the mobile augmented reality technology assisted students in associating language learning with the physical objects in the environment. The features of the technology (i.e. location-based data) offered students real-time context-aware information that helped students in contextualizing the learning.

2) Moblogs were utilized for collaboration in groups (Petersen, 2007; Cochrane 2008; Laine \& Suhonen, 2008; Huang et al., 2009; Cook et al., 2011; Smith et al., 2011b). Huang et al. (2009) discovered that the collaboration in moblogs is beneficial due to its capability in facilitating online group discussions that do not require face-to-face interaction. This mode of discussion can remove social anxiety aspects such as peer pressure or uncomfortable feeling of talking with others. Additionally, this mode of interaction can resolve the problem of group coordination, as students gradually learn how to coordinate discussions to avoid miscommunication and lack of direction (Huang et al., 2009).

3) Moblogs were used as instant interaction and communication tool for learning (Shao et al., 2007; Cochrane, 2008; Huang et al., 2009). Huang and colleagues (2009) study found that moblogs are an easy and convenient medium for learning as they can be accessed anywhere, anytime. In the research, $82.5 \%$ of the students surveyed indicated that they were satisfied with the capability of moblog to facilitate the discussion of urgent learning matters. Using mobile devices, students consulted their peers as well as their instructors via comments and entries in moblogs and were able to receive instantaneous feedback. In another study, moblogs were utilized as an interaction and communication platform that shows substantial amount of effectiveness towards achievement of meaningful learning (Shao et al., 2007).

4) Moblogs were used as personal learning diaries (Haddon \& Kim, 2007; Petersen, 2007; Goankar et al., 2008). In Haddon and Kim's (2007) study, the content analysis of moblogs showed that students used moblogs to record their daily activities. In addition, the analysis revealed that they used moblogs to express their feelings and emotions via entries, comments and interface themes. For example, one student uploaded an image of herself to express her emotional state for that particular day. Similarly, Shao et al. (2007) discovered that students also shared their difficulties in learning and understanding of the culture in students' studying environment. It was observed that moblogs could be used to provide information on learning experiences, culture and difficulties of becoming a student in a new learning environment and provide advice on how to adapt to these circumstances.

5) Moblogs facilitated learning at students'own time and pace (Cochrane, 2008; Huang et al., 2009). Students in Cochrane (2008) indicated that moblogs allowed them to learn according to their own time and pace due to the fact that they could refer to learning materials anywhere, whether on campus or off-campus. They added that evening times were the most convenient time for creating postings in moblogs. It was indicated that moblogs provided them with the capability of "capsuling" events in their free- time, which in turn contributed to informal learning while "on-the-go".

6) Moblogs were used to provide feedback on instruction (Trafford, 2005; Wishart, 2009). For example, students in Trafford's (2005) study used moblogs to give opinions on the pace of lectures and observations of instructors' lecturing style. For example, one of the students stated that the lecture's pace was too fast and that a pause was needed for explanation of concepts. On observation of instructor's lecturing style, another student commented that the instructor should interact more with the audience, as the instructor did not verify that the whole class understood a concept before moving on to the next. The research also revealed that moblogs were used for instructors to identify students' level of motivation in learning. Instructors observed students' motivation level by reviewing their comment on postings such as a student was fully motivated although she found mathematics to be hard for her. Likewise, Wishart (2009) showed that moblogs provided a platform for instructors to evaluate teaching practices of trainees. Moblogs also allowed trainees to record their teaching practices for their own reflection. However, the study equally revealed that trainees did not prefer sharing their teaching observations and reflections online with instructors and other trainees from outside their school.

7) Moblogs were utilized for reflection in learning (Morken \& Diviniti, 2005; Trafford, 2005; Shao et al., 2007; Cochrane, 2008; Laine \& Suhonen, 2008; Din et al., 2011). For example, Shao et al. (2007) reported moblogging to promote self-reflection (synchronous and asynchronous) and real-time peer-to-peer reflection among students. Synchronous self-reflections were observed to occur during the posting of comments, where postings were reviewed and checked for spelling errors and grammatical mistakes before published on the web. This is due to the fact that students wanted to present themselves well. Asynchronous self-reflections occurred in the process of creating new moblogs, reflecting on their own moblogs as well as those of their peers. The reflection was reported to assist students in gaining ideas for new moblogs. In relation, real-time peer-to-peer reflections were observed to happen as students posted real-time constructive comments on their peers' postings by using text, 
images, video and audio via their mobile devices. Similarly, Killi et al. (2009) discovered that students used video moblogs to explain abstract concepts in a Human Computer Interaction course. Although results indicated that students showed a tendency of having misconceptions in their video moblogs, the study revealed interesting results in the sense that video moblogs have potential in assisting students to grasp abstract concepts.

\subsection{Perceived Effects of Moblogs on Learning}

In our review, researchers were interested to review the perceived affective effects of moblogs on students' learning, in terms of satisfaction and attitude, which were assessed through surveys, interviews and content analysis. Most of the students agreed that moblogs increased their motivation in learning due to context-sensitive learning support as well as group work and interaction facilities afforded by moblog technology (Goankar et al., 2008; Herrington, 2009; Cochrane, 2009; Huang et al., 2009). As for context-sensitive learning support, students indicated that real-time upload access as well as real-time sharing capabilities was cited as some of the reasons that contributed towards their high level of satisfaction towards moblogs (Goankar et al., 2008). Students stated that these capabilities provided a very attractive atmosphere and community for learning among their peers (Cochrane, 2008; Huang et al., 2009). In relation, fascination with using the latest technology and new methods for instruction delivery were other reasons cited (Herrington, 2009).

Interestingly, moblogs have been perceived to have social effects on students. Formative feedback and content analysis of moblogs in Haddon and Kim's (2007) study discovered that moblogs can cause students to have a sense of peer pressure to update their moblogs frequently, so as to not be left out the community. Number of visitors was also observed to be a concern of the students, as a higher number would indicate the interestingness of their moblogs. Several methods such as change of color and uploading of new images were revealed as methods to increase total visitors. Subsequently, similar to findings of Sim and Hew's (2010) study on weblogs, researchers discovered that students were not in the favor of moblogging for the public as they were concerned with privacy issues as well as their daily routines were uninteresting to be shared for a wider public.

Our review also identified issues and negative responses towards the perceptions of moblogs for instruction and learning. The negative perceptions can be categorized into personal factors and technical factors. Personal factors were related to negative perception on the importance of moblogs towards reflection of learning (Wishart, 2009), low level of moblog usage for studying purposes (Oliver \& Goerke, 2007), low attention spans during learning (Trafford, 2005), as well as difficulty in understanding theoretical concepts for reflection in moblog (Killi et al., 2009). For example, in Trafford's (2005) study, it was indicated that usage of moblog tends to promote short attention spans among students due to fact that moblogs offer viewing instantaneous events rather than providing the student with persistent reflection.

On the other hand, technical factors include: (i) time consuming in terms of creating posts (Cochrane, 2008), (ii) blogging was hard for non-technical students (Petersen, 2007; Killi et al., 2009; Comas-Quinn et al. 2009), (iii) difficulty of reading due to small screen display of mobile devices (i.e. PDA) (Wishart, 2009), (iv) issues with writing styles causing difficulties in understanding moblog content (Trafford, 2005), (v) lack of focus in discussions and comments; and (vi) coordination in groups during collaboration (Huang et al., 2009).

\section{Moblogs: The Way Forward in Learning?}

With regards to moblog usages, the findings lead us to a better understanding of the factors that could promote the use of moblogs for learning. As a result, the following suggestions may be implemented in facilitating moblog usage.

\subsection{Discussion on Moblogs Usage in Learning}

First, in promoting context-sensitive learning, educators could consider implementing moblogs in learning environments where learners can exploit the full potential of context-aware information. For example, in teaching novice researchers about complex science experiments (Hwang et al., 2009), context-aware information was gained from the lab environment (i.e. temperature) as well as learner feedback (to the learning device), where temperature was utilized as a safety mechanism - determining whether the equipment used was safe or not, and learner feedback was used to determine the next learning activity. In addition, ubiquitous learning strategies and models (refer to Hwang et al., 2008), such as "cooperative data collecting and problem solving" via moblogs or "online tests based on real-world observations" could be integrated to promote context-sensitive learning.

Second, in terms of collaborative learning, moblogs could be used to facilitate asynchronous online group discussions. The fact that Huang et al. (2009) reported that moblogs seem to remove social anxiety aspects can be beneficial for learners who have high levels of diffidence and possess low self-esteem. However, although this scenario may intrigue such learners to collaborate, the scenario has to be dealt with carefully as it may cause 
other anxieties to surface, such as keeping up with the pace of posting of other mobloggers or the pressure of attracting larger number of readers.

Third, as moblogs were reported to allow for instantaneous feedback on learning, this technology could be utilized as a problem-solving hub where the discussion is not only confined to peers and instructors in their classroom nucleus, but to a larger audience such as faculty or university level. This would allow for insights and perspectives from diverse span of contributors and may aid students in obtaining alternative solutions to a given problem. In addition, moblogs were also suggested to assist students to study in their own time and pace. Researchers could use this advantage in removing the time barrier that exists in classroom lectures, as learners could use moblogs to learn in their own pace and time.

Fourth, with regards to moblogs as personal learning diaries and reflection for learning, educators could consider using moblogs as individual and group reflection tool, where learners would analyze and reflect on learning activities or lectures - allowing for self-assessment and peer assessment of learning. For instance, in a study conducted by Yang (2010), it was reported that reflective journals increased students' writing skills by applying reflection-in-action and reflection-on-action in their reflections and improving them by self-correction and peer review techniques. Nevertheless, in facilitating peer review, there is the issue of comment sensitivity whereby one learner may deem a comment to be constructive or critical, whereas another may deem a comment to be intrusive or harsh. Educators could apply measures in curbing unconstructive comments such as in Fessakis et. al's (2008) study, where features of constructive comments (provided by group blogs) helped students to overcome their initial hesitation in peer commenting.

\subsection{Discussion on Perceived Effects of Moblogs on Learning}

First, educators should consider development of curriculum that can suit the inclusion of moblogs as learning and teaching tools. Whether the mode of curricula implementation is to be performed on a full online learning basis, or on a blended learning basis; the development of such curricula should be developed with the inclusion of stakeholders from different fields of expertise - instructors, students, experts, and technical staff. Suitable approaches include user-centered approaches (e.g. participatory design - see Caroll et al., 2000), or frameworks that cater for instructors' involvement with technology such as Technological Pedagogical Content Knowledge (see Kohler \& Mishra, 2005) can also be conducted in resolving the limitations. In addition, learning activities need to be designed to suit the diverse learning styles of students along with the benefits that moblogs offer. As moblogs are reflective in nature, learning using the technology could be more biased towards reflective learners. A balance in exploiting the technology's attributes, such as mobility, portability and context-awareness, could be a potential solution in catering to students who are more active and exploratory - leading to a more effective means for learning. Furthermore, curriculum designers should consider that designing curricula for mobile blogging involves delegating the task of the instructor towards mobile technology, thus changing the learning approach from an instructor-centered approach to a more student-centered one (Kukulska-Hulme, 2010). Such curricula should also be designed with the inclusion of assessment tools for measuring students' learning achievement (Stes et al., 2010), as well as their attitude towards learning (e.g. self-efficacy, see van Dinther et al., 2011) with moblogs.

Second, with regards to the limitation in writing styles and discussion focus (Trafford, 2005; Wishart, 2009), as suggested by Brownstein and Klein (2006), educators could consider underlining a set of rules for usage of understandable language upon creation of postings. In addition, providing extra marks for providing critical comments in moblogs is another solution that can be taken into consideration. Nevertheless, these solutions should be applied with caution, as confining students to a set of language rules may limit the students in expressing themselves well, which may further affect the quality and authenticity of the moblog postings and comments.

Third, regarding privacy issues in moblogs, researchers could consider making the moblogs private within a set of students. However, benefits and limitations of implementing this option should be weighed carefully as limiting the moblogs within a nucleus of students may impede an open space discussion with a wider community of learners. In contrast, such open space may invite unwanted postings.

Fourth, educators could consider applying means in aiding students and instructors in familiarizing students and instructors with moblog technology. Hands-on training and step-by-step guidelines on moblogging processes are some of the measures that could increase their confidence in using the technology (Sim \& Hew, 2010), thus removing their negative perception that moblogging is difficult and time consuming.

Fifth, educators could also design mobile learning tasks that address the issues pointed out by Frohberg et al. (2009), which includes control, tools, context, communication, subject, and object(ive). For example, in 
addressing the issue of tools, the usage of the learning tool (in this case, moblogs) in a particular learning activity should be defined beforehand as it could impact the learning process. As Frohberg et al. (2009) scales the issue of "tools" in a five-scale continuum (1-content delivery; 2-interaction for motivation and control; 3-reflective interaction; 4-reflective data collection; 5-content construction), the effectiveness of moblogs to facilitate learning would depend on its purpose on the scale whether for solely content delivery or for reflective data collection and content construction.

Sixth, several technical issues need to be addressed in the implementation of mobile blogging in educational institutions. These issues include privacy, device support, cost, and scalability. The privacy issue of moblog deployment needs to address moblog deployment on a private domain (university domain) or a public one. When considering the issue of privacy, factors such as institutional reputation and intellectual property (Traxler, 2009), also fall into consideration - a moblog with mediocre discussions among students and instructors may give an unwanted effect on the institutions' reputation; learning materials provided by instructors as well as student-generated content on a public domain raise concerns related to intellectual property. Subsequently, effective deployment of mobile blogging depends on wireless connections in educational institutions, where there is a need of facilitation of all types of mobile devices ranging from laptops and tablet PCs to smartphones and mobile phones as well as integration of these devices into the institution's ICT structure (Wishart, 2009). As for off-campus connections, a collaboration of educational institutions and mobile carriers needs to be established in reducing the costs of sending and receiving data packets over $3 \mathrm{G}$ networks. In relation, it has been observed that mobile blogging implementation becomes more challenging as the scale of deployment becomes larger. Deploying mobile blogging for a course or at faculty may be easier to handle rather than implementing the technology at the university level. Moreover, factors such as students and instructors' learning and teaching culture, their practices and expectations towards mobile technology also need to be considered in providing mobility to users (Traxler, 2009).

\subsection{Overall Discussion}

Our review identified a number of drawbacks in previous empirical studies of moblogs for higher education. We found that the majority of the reviewed studies $(69 \%)$ only focused on either quantitative or qualitative method. Such limitations - only implementing one particular method (quantitative or qualitative) in the research may lead to bias in terms of results gathered. Application of a combination of, qualitative and quantitative methods could yield in interesting results as the qualitative results could complement the quantitative results and vice versa.

We also identified that the previous studies seem to emphasize their research towards students and less emphasis was given towards instructors. Studies of instructors could be conducted in the following areas: (i) moblogs as reflection tools of instruction; (ii) moblogs as a tool for creation of a "instructor-to-instructor community" in which the instructors could receive feedback on their teaching; and (iii) methods of implementing moblogs effectively according to instructors' teaching styles and students' learning styles. These instructor-centered studies would be beneficial in liaising the instructor-technology relationship as well as reducing the gap between instructors, students, and technology.

In addition, duration of the study was identified as a limitation. Most of the research studies were conducted over a period of not more than four months (i.e. one semester). According to Sim and Hew (2010), a relatively short duration may cause: (i) a student to be affected by novelty effects; and (ii) the nature of moblogs that requires reflective learning may require a longer duration to be appreciated by the student. Novelty effects translates to a state where students are affected by new technology (i.e. students may show a higher degree of attention towards technology that is new to them) that in turn may result in a certain degree of bias towards moblogs content and total of moblog postings. As such, future research should investigate the moblogging effects for longer periods, about a period of one year or more, such as conducted by Wishart (2009), to assess whether perception of moblogs changes over time, and reassure that moblogs have significant impact on learning as well as instruction.

\section{Conclusion}

This research has primarily reviewed articles on mobile blog technology. Future research could investigate the possibilities of combining this technology with other web 2.0 technologies, such as mobile augmented reality and mobile tagging, in creating integrated solutions for maximizing the learning experience. In addition, educators could also study the cultural and social effect of different geographical context on usage of moblogs. The values that certain countries nurture and practice might have a large influence on moblog usage and its effect on learning and instruction. The findings in this review suggest that moblogs could be used as learning tool to enhance learning and instruction in higher education. Albeit promising outcomes from research on mobile blogs, this research field is rather new and further understanding of its usage and impacts is needed. As the research in 
this field holds much promise, it is hoped that the review will be beneficial to researchers and educators interested in conducting new studies or continuing current research on mobile blogs in higher educational settings.

\section{Acknowledgement}

We would like to thank the Malaysian Ministry of Higher Education, the Personalized E-learning Group (Faculty of Education, National University Malaysia), the e-Learning Lab (Aalborg University) as well as individuals, especially Prof. Dr. Kamaruzaman Jusof, who have directly and indirectly contributed to the completion of this paper.

\section{References}

Ally, M. (Ed.). (2009). Mobile Learning: Transforming the Delivery of Education and Training. Edmonton: AU Press.

Beale, R. (2006). Supporting social interactions with smartphones. IEEE Pervasive Computing, 4(2), 35-41. http://dx.doi.org/10.1109/MPRV.2005.38

Brownstein, E., \& Klein, R. (2006). Blogs: Applications in science education. Journal of College Science Teaching, 35(6), 18-22.

Carroll, J. M., Chin, G., Rosson, M. B., \& Neale, D. C. (2000). The development of cooperation: Five years of participatory design in the Virtual School (pp. 239-251) Proceedings on Designing Interactive Systems: Processes, Practices, Methods, and Techniques.

Cochrane, T. (2008). Mobile Web 2.0: The new frontier (pp. 177-186). Proceedings of ASCILITE Melbourne 2008.

Comas-Quinn, A., Mardomingo, R., \& Valentine, C. (2009). Mobile blogs in language learning: Making the most of informal and situated learning opportunities. ReCALL, 21(1), 96-112. http://dx.doi.org/10.1017/S0958344009000032

Cook, J., Pachler, N., \& Bachmair, B. (2011). Ubiquitous mobility with mobile phones: A cultural ecology for mobile learning. E-Learning and Digital Media, 8(3), 181-196. http://dx.doi.org/10.2304/elea.2011.8.3.181

Davis, M., van House, N., Towle, J., King, S., Ahern, S., Burgener, C., ... Rothenberg, M. (2005). MMM2: Mobile media metadata for media sharing (pp.1335-1338). Proceedings of CHI '05 extended abstracts on Human Factors in Computing Systems (CHI '05).

Din, R., Nordin, N., Jusoff, K., Nordin, M. S., Zakaria, M. S., Mastor, K. A., \& Embi, M. A. (2011). Hybrid E-Training Measurement Tool: Reliability and Validity. Middle-East Journal of Scientific Research, 7(2), 184-188.

Doring, N., \& Gundolf, A. (2006). Your life in snapshots: Mobile weblogs. Knowledge, Technology, \& Policy, 19(1), 80-90. http://dx.doi.org/10.1007/s12130-006-1018-2

Ekström, H., Furuskär, A., Karlsson, J., Meyer, M., Parkvall, S., Torsner, J., \& Wahlqvist, M. (2006, March). Technical solutions for the $3 \mathrm{G}$ long-term evolution. IEEE Communications Magazine, 38-45. http://dx.doi.org/10.1109/MCOM.2006.1607864

Ertmer, P. A. (2005). Teacher pedagogical beliefs: The final frontier in our quest for technology integration? Educational Technology Research \& Development, 53(4), 25-39. http://dx.doi.org/10.1007/BF02504683

Evans, C. (2008). The effectiveness of m-learning in the form of podcast revision lectures in higher education. Computers \& Education, 50, 491-498. http://dx.doi.org/10.1016/j.compedu.2007.09.016

Fessakis, G., Tatsis, K., \& Dimitracopoulou, A. (2008). Supporting "Learning by Design" Activities Using Group Blogs. Educational Technology \& Society, 11(4), 199-212.

Frohberg, D., Göth, C., \& Schwabe, G. (2009). Mobile learning projects - A critical analysis of the state of the art. Journal of Computer Assisted Learning, 25(4), 307-331. http://dx.doi.org/10.1111/j.1365-2729.2009.00315.x

Haddon, L., \& Kim, S. D. (2007, January-March). Mobile phones and web-based social networking - Emerging practices in Korea with Cyworld. Journal of the Communications Network, 6, 5-12.

Herring, S. C., Scheidt, L. A., Bonus, S., \& Wright, E. (2004). Bridging the gap: A genre analysis of weblogs. Proceedings of the 37th Hawaii international conference on system sciences.

Herrington, A. (2009). Using a smartphone to create digital teaching episodes as resources in adult education. In 
J. Herrington, A. Herrington, J. Mantei, I. Olney, \& B. Ferry (Eds.), New technologies, new pedagogies: Mobile learning in higher education. Wollongong: Faculty of Education, University of Wollongong.

Herrington, J., \& Oliver, R. (2000). An instructional framework for authentic learning environments. Educational Technology Research and Development, 48(3), 23-48. http://dx.doi.org/10.1007/BF02319856

Huang, Y. M., Jeng, Y. L., \& Huang, T. C. (2009). An educational mobile blogging system for supporting collaborative learning. Educational Technology \& Society, 12(2), 163-175.

Hussin, S., Manap, M. R., Amir, Z., \& Krish, P. (2012). Mobile learning readiness among Malaysian students at higher learning institutes. Asian Social Science, 8(12), 276. http://dx.doi.org/10.5539/ass.v8n12p276

Hwang, G. J., Tsai, C. C. \& Yang, S. J. H. (2008). Criteria, strategies and research issue of context-aware ubiquitous learning. Educational Technology \& Society, 11(2), 81-91.

Hwang, G. J., Yang, T. C., Tsai, C. C., \& Yang, S. J. H. (2009). A context-aware ubiquitous learning environment for conducting complex science experiments. Computers \& Education, 53(2), 402-413. http://dx.doi.org/10.1016/j.compedu.2009.02.016

Ito, M. (2002). Mobiles and the appropriation of place. Retrieved from http://www.receiver.vodafone.com

Killi, K., Multisilta, J., Suominen, M., \& Ketamo, H. (2009). Learning experiences on mobile social media (pp. 535-542). Proceedings of the 17th International Conference on Computers in Education, ICCE 2009.

Koehler, M. J., \& Mishra, P. (2005). Teachers learning technology by design. Journal of Computing in Teacher Education, 21(3), 94-102.

Kukulska-Hulme, A. (2010). Learning Cultures on the Move: Where are we heading? Educational Technology \& Society, 13(4), 4-14.

Lee, M. J. W., \& Chan, A. (2005). Exploring the potential of podcasting to deliver mobile ubiquitous learning in higher education. Journal of Computing in Higher Education, 18(1), 94-115. http://dx.doi.org/10.1007/BF03032726

Morken, E. M., \& Divitini, M. (2005). Blending mobile and ambient technologies to support mobility in practice based education: A case of teacher education. Proceedings of the 4th World Conference on mLearning (pp. 25-28).

Nordin, N., Embi, M. A., \& Yunus, M. M. (2010). Mobile learning framework for life long learning. Procedia Social and Behavioral Sciences, 7, 130-138.

Oliver, B., \& Goerke, V. (2007). Australian undergraduates' use and ownership of emerging technologies: Implications and opportunities for creating engaging learning experiences for the Net Generation. Australasian Journal of Educational Technology, 23(2), 171-186.

Petersen, S. A. (2007). Community blog: Enhanced support for mobile collaborative language learners. Proceedings of the 2007 International Symposium on Collaborative Technologies and Systems (CTS 2007). http://dx.doi.org/10.1109/CTS.2007.4621773

Pierce, T. (2009). Social anxiety and technology: Face-to-face communication versus technological communication among teens. Computers in Human Behavior, 25(6), 1367-1372. http://dx.doi.org/10.1016/j.chb.2009.06.003

Rekkedal, T., \& Dye, A. (2007). Mobile distance learning with PDAs: Development and testing of pedagogical and system solutions supporting mobile distance learners. The International Review of Research in Open and Distance Learning, 8(2).

Richardson, I., Third, A., \& MacColl, I. (2007). Moblogging and belonging: New mobile phone practices and young people's sense of social inclusion. Proceedings of the 2nd international conference on Digital interactive media in entertainment and arts (DIMEA '07).

Ryberg, T., \& Christiansen, E. (2008). Community and social network sites as technology enhanced learning environments. Technology, Pedagogy and Education, 17(3), 207-219. http://dx.doi.org/10.1080/14759390802383801

Shao, Y., Crook, C., \& Kolevas, B. (2007). Motivating learning through the community of mobile blog. In I. Arnedillo-Sánchez, M. Sharples, \& G. Vavoula (Eds.), Beyond Mobile Learning Workshop (pp. 26-29). Dublin: Trinity College Dublin Press.

Sharples, M, Arnedillo-Sánchez, I., Milrad, M., \& Vavoula, G. (2009). Mobile learning: Small devices, big issues. 
In S. Ludvigsen, N. Balacheff, T. de Jong, A. Lazonder, \& S. Barnes (Eds.), Technology-enhanced learning: Principles and products. Dordrecht: Springer. http://dx.doi.org/10.1007/978-1-4020-9827-7_14

Sim, J. W. S., \& Hew, K. F. (2010). The use of weblogs in higher education settings: A review of empirical research. Educational Research Review, 5(2), 151-163. http://dx.doi.org/10.1016/j.edurev.2010.01.001

Siraj, S., \& Norman, H. (2011). Current trends and prospects of mLearning. In S. Siraj, F. Siraj, \& H. Norman (Eds.), mLearning: A new curriculum dimension. Kuala Lumpur: University Malaya Press.

Smith, C., Bradley, C., Cook, J., \& Pratt-Adams, S. (2011). Designing for Active Learning: Putting learning into context with mobile devices. In A. D. Olofsson, \& J. O. Lindberg (Eds.), Informed Design of Educational Technologies in Higher Education: Enhanced learning and teaching. Hershey, PA: IGI Global. http://dx.doi.org/10.4018/978-1-61350-080-4.ch016

Stes, A., Min-Leliveld, M., Gijbels, D., \& van Petegem, P. (2010). The impact of instructional development in higher education: The state-of-the-art of the research. Educational Research Review, 5(1), 25-49. http://dx.doi.org/10.1016/j.edurev.2009.07.001

TNS. (2011). Mobile Press Release: TNS study reveals penalty for not keeping up in relentlessly changing mobile category. Retrieved May 11, 2011, from http://discovermobilelife.com

Trafford, P. (2005). Mobile blogs, personal reflections and learning environments. Ariadne, 44.

Traxler, J. (2009). Current state of mobile learning. In M. Ally (Ed.), Mobile Learning: Transforming the Delivery of Education and Training. Edmonton: AU Press.

Van Dinther, M., Dochy, F., \& Segers, M. (2011). Factors affecting students' self-efficacy in higher education. Educational Research Review, 6(2), 95-108. http://dx.doi.org/10.1016/j.edurev.2010.10.003

Wishart, J. M. (2009). Use of Mobile Technology for Teacher Training. In M. Ally (Ed.), Mobile Learning: Transforming the Delivery of Education and Training. Edmonton: AU Press.

Wong, L. H., \& Looi, C. K. (2011). What Seams Do We Remove in Mobile Assisted Seamless Learning? A Critical Review of the Literature. Computers and Education, 57(4), 2364-2381. http://dx.doi.org/10.1016/j.compedu.2011.06.007

Yang, Y. F. (2010). Students' reflection on online self-correction and peer review to improve writing. Computer \& Education, 55(3), 1202-1210. http://dx.doi.org/10.1016/j.compedu.2010.05.017

\section{Copyrights}

Copyright for this article is retained by the author(s), with first publication rights granted to the journal.

This is an open-access article distributed under the terms and conditions of the Creative Commons Attribution license (http://creativecommons.org/licenses/by/3.0/). 